\title{
CORRESPONDENCE
}

\section{CO-EXISTING PYROXENES}

SIR.-Three papers dealing with the distribution of $\mathrm{Mg}$ and $\mathrm{Fe}$ between co-existing orthopyroxene and clinopyroxene have recently appeared in the Geological Magazine. Muir and Tilley (1958) concluded that the distribution is the same for metamorphic and plutonic igneous rocks. Wilson (1960) suggested that the distribution may vary as a function of temperature. O'Hara (1960) arrived at a conclusion which concurs with that of Muir and Tilley. In each paper the distribution is discussed in terms of tie-lines in a three-component diagram; the intersection point of a side of the diagram and the projection of a tie-line is taken as a measure of the distribution.

The subject can be examined from a thermodynamic viewpoint (Ramberg and DeVore, 1951). The distribution of $\mathrm{Mg}$ and $\mathrm{Fe}$ between two minerals can be expressed by use of a distribution diagram (Kretz, 1959). When this is done for co-existing pyroxenes from six Indian charnockites studied by Howie (1955) we obtain a curve, the shape of which indicates that both phases are ideal mixtures (Mueller, 1960). Thus the distribution coefficient can be taken as a direct measure of the distribution of $\mathrm{Mg}$ and $\mathrm{Fe}$ between the two minerals. The distribution coefficient $\left(\mathrm{K}_{\mathrm{D}}\right)$ has the form (Ramberg and DeVore, 1951):

$$
\mathrm{K}_{\mathrm{D}}=\frac{\mathrm{X}^{\mathrm{o}}}{1-\mathrm{X}^{\mathrm{o}}} \cdot \frac{1-\mathrm{X}^{\mathrm{c}}}{\mathrm{X}^{\mathrm{c}}}
$$

where $\mathrm{X}^{0}=\mathrm{Mg} /\left(\mathrm{Mg}+\mathrm{Fe}^{2+}\right)$ in orthopyroxene, and $\mathrm{X}^{\mathrm{c}}=\mathrm{Mg} /(\mathrm{Mg}+$ $\mathrm{Fe}^{2+}$ ) in clinopyroxene.

Values of $\mathrm{K}_{\mathrm{D}}$ for orthopyroxene-clinopyroxene combinations from two groups of rocks are presented in Table 1. The first group of rocks was supposedly equilibrated at metamorphic temperatures and the second group at near-liquidus temperatures. Note that $\mathrm{K}_{\mathrm{D}}$ is nearly constant in the first group and consistently higher in the second group.

\section{TABLE 1}

\begin{tabular}{|c|c|c|c|c|}
\hline Spec. No. & $\mathrm{K}_{\mathrm{D}}$ & & Source & \\
\hline Metamo & ic rock & & & \\
\hline 3709 & 0.553 & Hor & (1955) & \\
\hline 4645 & 0.510 & 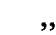 & & \\
\hline 2270 & 0.532 & " & " & \\
\hline 2941 & 0.561 & ," & $"$ & \\
\hline $4642 \mathrm{~A}$ & 0.567 & 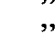 & $"$ & \\
\hline 115 & 0.598 & ," & d"Tilla & (1958 \\
\hline $\begin{array}{l}\mathrm{O} \\
\mathrm{S}\end{array}$ & $\begin{array}{l}0.578 \\
0.564\end{array}$ & Mu & la inle. & \\
\hline $35-5$ & 0.541 & Wä & 1957)" & $"$ \\
\hline $35-6$ & 0.548 & ", & $"$ & \\
\hline $35-8$ & $0 \cdot 534$ & $"$ & 3 & \\
\hline $35-9$ & 0.515 & ," & ," & \\
\hline $35-19$ & $0 \cdot 525$ & $"$ & ", & \\
\hline
\end{tabular}

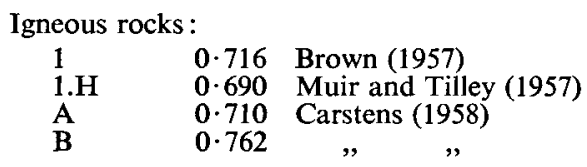

Three rocks studied by Muir and Tilley (1958) are of special interest. The specimens are numbered $X, R$, and $T$, and contain mineral pairs which yield $K_{D}$ values of $0.856,0.776$, and 0.782 respectively. These are metamorphic 
rocks with values of $\mathrm{K}_{\mathrm{D}}$ characteristic of igneous rocks. Specimen $\mathrm{X}$ is a metamorphosed basalt and the remaining two may also have experienced igneous temperatures, as indicated by the presence of olivine. The possibility exists that $K_{D}$ in the three rocks is a relic of a pre-metamorphic high-temperature equilibrium.

On theoretical grounds we find that $\mathrm{K}_{\mathrm{D}}$ is dependent on (1) temperature, (2) pressure (Ramberg and DeVore 1951), and (3) variable concentrations of a third element (Kretz, 1961). It is reasonable to suspect that large variations in $K_{D}$ (Table 1) have resulted from a variation in the equilibration temperature. It is uncertain, however if small variations in $\mathbf{K}_{\mathbf{D}}$ (as found in the first group of rocks in Table 1) may be attributed entirely to the temperature dependence of the distribution coefficient.

The subject will be discussed in detail in a forthcoming paper. At present I should like to make a special plea to abandon the meaningless operation of projecting tie-lines and to propose that we discuss the distribution of $\mathrm{Mg}$ and $\mathrm{Fe}$ in co-existing pyroxenes in terms of the distribution coefficient.

\section{REFERENCES}

Brown, G. M., 1957. Pyroxenes from the early and middle stages of fractionation of the Skaergaard intrusive, East Greenland. Miner. Mag., 31, 511-543.

Carstens, H., 1958. Note on the distribution of some minor elements in co-existing ortho- and clino-pyroxene. Norsk. geol. Tidsskr., 38, 257-260.

HowIE, R. A., 1955. The geochemistry of the charnockite series of Madras, India. Trans, roy. Soc. Edinb., 62, 725-768.

KreTz, R., 1959. Chemical study of garnet, biotite, and hornblende from gneisses of south-western Quebec, with emphasis on distribution of elements in co-existing minerals. J. Geol., 67, 371-402.

1961.Some applications of thermodynamics to co-existing minerals of variable composition. Examples: orthopyroxene-clinopyroxene and orthopyroxene-garnet. (in press).

MUeller, R. F., 1960. Compositional characteristics of equilibrium relations in mineral assemblages of a metamorphosed iron formation. Amer. J. Sci., 258, 449-497.

Muir, I. D., and C. E. Tilley, 1957. Contributions to the petrology of Hawaiian basalts, I. The picrite basalts of Kilauea. Amer. J. Sci., 255, 241-253.

1958. The compositions of co-existing pyroxenes in metamorphic assemblages. Geol. Mag., 95, 403-408.

O'HARA, M. J., 1960. Co-existing pyroxenes in metamorphic rocks. Geol. Mag., 96, 498-503.

Ramberg, H., and G. W. DeVore, 1951. The distribution of $\mathrm{Fe}^{++}$and $\mathrm{Mg}^{++}$ in co-existing olivines and pyroxenes. J. Geol., 59, 193-210.

WARD, R. F., 1959. Petrology and metamorphism of the Wilmington Complex, Delaware, Pennsylvania, and Maryland. Bull. Geol. Soc. Amer., 70, 1,425-1,459.

Wilson, A. F., 1960. Co-existing pyroxenes: Some causes of variation and anomalies in the optically derived compostional tie-lines, with particular reference to charnockitic rocks. Geol. Mag., 97, 1-17.

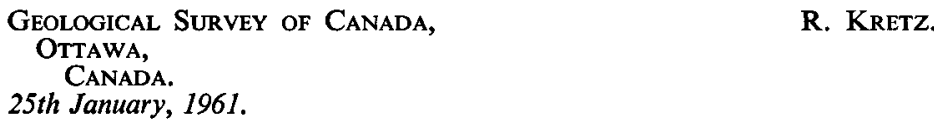

